\title{
QUANTITATIVE ANALYSIS OF UREASE BY ULTRAVIOLET ABSORPTION
}

\author{
ITSURO MATSUO and GUNJI MAMIYA \\ Department of Biochemistry and Department of Dermatology, \\ School of Medicine, \\ Keio University, Tokyo, Japan
}

(Received for publication July 10, 1968)

It is easy and advantageous way to estimate the protein quantities with their absorbance in ultraviolet region. Quantitative analysis of urease by measuring ultraviolet absorption has been reported already by Gorin ${ }^{1}$ and Reithel. ${ }^{2}$ However, acetone used in the procedure of urease preparation has ultraviolet absorption which interferes with protein assay.

In this paper, effects of contaminated acetone on ultraviolet absorption of urease was investigated.

\section{MATERIALS AND METHODS}

Urease was prepared from Japanese jack bean by the procedure previously described $^{3}$ except that centrifugations at $6,000 \mathrm{xg}$ instead of 8,000 or $27,000 \mathrm{xg}$ were equally appropriate for each centrifugal steps of preparation and the enzyme was crystallized three or four times by the procedure of Dounce.4 Purity of urease was checked by the criteria of analytically ultracentrifugal pattern and specific activity. Sodium hypobromite azotometry of Iwasa$\mathrm{ki}^{5,6}$ after Kjeldahl digestion was applied for nitrogen contents determination of urease in solutions. It was reported by Sumner ${ }^{7}$ that urease contained $16 \%$ of nitrogen, therefore calculation of protein quantity from its nitrogen content was based on this data. Enzymic activity of urease was evaluated by titraiton method with $0.1 \mathrm{~N}$ according to the proceudre previously described. Hitachi Spectrophotometer (139 type) was used for ultraviolet absorption measurgnents. 


\section{RESULTS}

Three times crystallized urease was dissolved in, and dialyzed against 1/30 $M$ phosphate buffer at $\mathrm{pH} 6.0,6.5,7.0,7.5$ and 8.0 , and 1/50 $M$ phosphate buffer, $\mathrm{pH}$ 7.0. After centrifugation at $0^{\circ} \mathrm{C}$, their absorption spectra from 240 to $360 \mathrm{~m} \mu$ were measured. Absorption curves of each urease solution at these $\mathrm{pH}$ were quite the same having an unique maximum at $278 \mathrm{~m} \mu$. The absorption curve at $\mathrm{pH} 7.0$ is presented in Fig. 1.

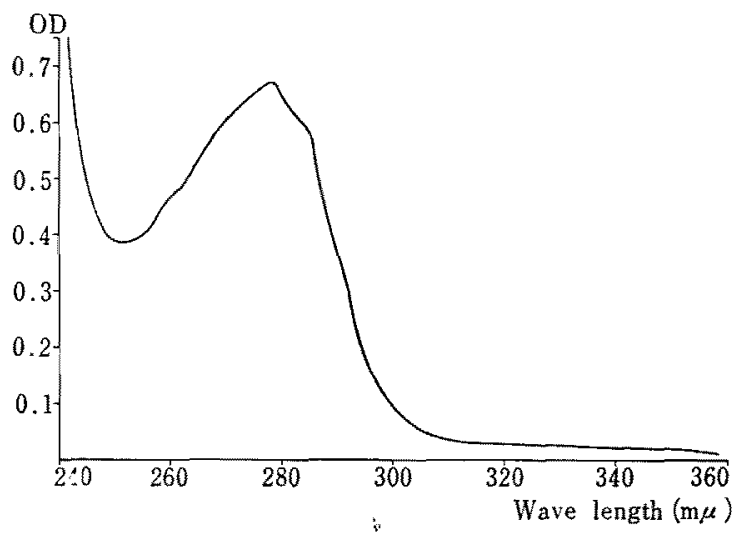

Fig. 1. Absorption spectra of urease at range from 240 to $360 \mathrm{~m} \mu$ in $1 / 50 \mathrm{M}$ phosphate buffer at $\mathrm{pH} 7.0$.

Three times crystallized urease was dissolved in 1/50 M pohsphate buffer, $\mathrm{pH} 7.0$ and dialyzed against the same buffer for three days in cold in order to remove acetone completely. This dialyzate was centrifuged at $0^{\circ} \mathrm{C}$, and diluted to several concentrations with the same buffer, and their ultraviolet absorption at $278 \mathrm{~m} \mu$ was determined. An aliquot of each sample was digested by Kjeldahl procedure and nitrogen contents were determined by the azotometry. Fig. 2 shows these results.

From this linear standard curve, following factor (F) was obtained.

$\mathrm{OD}$ at $278 \mathrm{~m} \mu \times \mathrm{F}=$ Urease $(\mathrm{mg} / \mathrm{ml}), \mathrm{F}=\mathbf{1 . 2 5}$

On the other hand, ultraviolet absorption and amounts of Kjeldahl nitrogen of non-dialyzed urease solution were determined as follows. Three or four times crystallized urease in $32 \%$ cold acetone were centrifuged at $0^{\circ} \mathrm{C}$. An aliquot of each sample was dissolved in $1 / 50 \mathrm{M}$ phosphate buffer, pH 7.0 , immediately after the centrifugation (Exp. 1 and 3 in Table 1), and another aliquots 


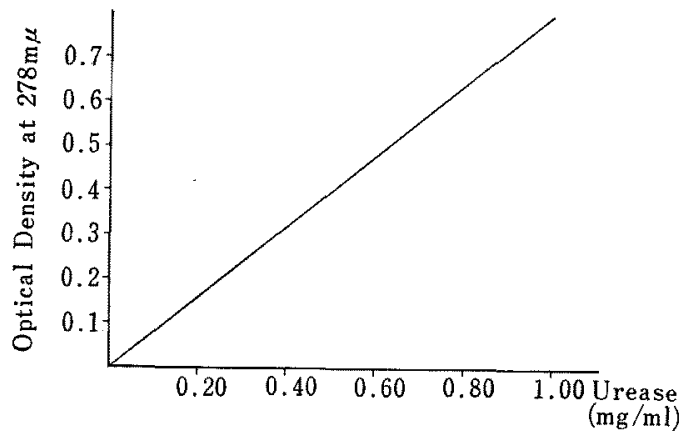

Fig. 2. Relationship between optical density at $278 \mathrm{~m} \mu$ and protein quantity by Kjeldahl azotometry of urease.

were left in a cold room for two hours in order to remove acetone (Exp. 2 and 4 in Table 1), and thereafter dissolved in the same buffer. All samples were then centrifuged at $0^{\circ} \mathrm{C}$, and their ultraviolet absorption at $278 \mathrm{~m} \mu$, enzymic activity, and nitrogen content by azotometry were determined as before, and results are shown in Table 1.

Table 1

\begin{tabular}{cccc}
\hline Exp. No. & $\begin{array}{c}\text { Optical density } \\
\text { at } 278 \mathrm{~m} \mu\end{array}$ & $\begin{array}{c}\text { Urease } \\
(\mathrm{mg} / \mathrm{ml})\end{array}$ & F \\
\hline 1 & 0.602 & 0.742 & 1.23 \\
2 & 0.478 & 0.535 & 1.11 \\
3 & 0.456 & 0.577 & 1.26 \\
4 & 0.304 & 0.376 & 1.23 \\
\hline
\end{tabular}

In exp. No.

1. Urease ( 3 times crystallized) was dissolved immediately in $1 / 50 \mathrm{M}$, pH 7.0 phosphate buffer.

2. Urease ( 3 times crystallized) was dried in cold room while two hours in order to remove acetone, thereafter dissolved in $1 / 50 \mathrm{M}$, pH 7.0 phosphate buffer.

3. Urease (4 times crystallized) was dissolved immediately in $1 / 50 \mathrm{M}, \mathrm{pH} 7.0$ phosphate buffer.

4. Urease (4 times crystallized) was dried in cold room while two hours in order to remove acetone, thereafter dissolved in $1 / 50 \mathrm{M}, \mathrm{pH} 7.0$ phosphate buffer.

\section{DISCUSSION}

Urease solution shows a characteristic absorption spectrum in the ultra- 
violet region with a maximum at $278 \mathrm{~m} \mu$, not at $272 \mathrm{~m} \mu$ reported by Gorin et al. ${ }^{1}$ (Fig. 1). Acetone used for preparation of urease shows a strong absorption near $278 \mathrm{~m} \mu$, too. However, urease solution dialyzed for three days was verified to be completely free from contaminating acetone and it was proved that optical density at $278 \mathrm{~m} \mu$ was exactly proportional to protein quantity (Fig. 2), i.e. 0.1 of $\mathrm{O} \mathrm{D}$ is equivalent to $125 \mathrm{mg}$ of urease protein per ml. As shown in Table 1, it was attempted to remove acetone by leaving urease crystals in open air in a cold room, but this trial was not succeeded. The cause of this unsuccess may be due to 1) the irregular ratio between precipitate quantity and its surface dimensions against open air 2) the irregular ratio between quantities of precipitate and of involved solvent.

\section{SUMMARY}

1) Urease solution shows a characteristic absorption in ultraviolet with a maximum at $278 \mathrm{~m} \mu$ at $\mathrm{pH}$ from 6.0 to 8.0 .

2) The equation, $\mathrm{O} \mathrm{D}$ at $278 \mathrm{~m} \mu \times \mathrm{F}=$ Urease $(\mathrm{mg} / \mathrm{ml}), \mathrm{F}=1.25$ was obtained when urease solution was completely free from acetone.

\section{ACKNOWLEDGEMENTS}

We are very grateful to Dr. K. Sekita, Professor of Biochemistry for his encouragement and advice.

\section{REFERENCES}

1. Gorin, G., Fuchs, E., Butler, L. G., Chopra, S. L., and Hersh, R. T.: Some properties of urease. Biochemistry, 1: 911-916, 1962.

2. Reithel, F. J. and Robbins, J. E.: Studies on protein multimers. 1. Urease. Arch. Biochem. Biophys., 120: 153-164, 1967.

3. Mamiya, G. and Gorin, G.: Urease. 5. Some observations on the procedure for its isolation. Biochim. Biophys. Acta., 105: 382-385, 1965.

4. Dounce, A. L.: An improved method for recrystallizing urease. J. Biol. Chem., 140: 307-308, 1941.

5. Iwasaki, K., Otsuki, M., and Nakazima, S.: On NaBrO-Azotometry. JuzenkaiZasshi, 42: 2132-2139, 1937. (in Japanese)

6. Gorin, G. and Chin, C. C.: Urease. 6. A new method of assay and the specific enzymic activity. Anal. Biochem., 17: 49-59, 1966.

7. Summer, J. B.: Urease. The Enzymes, vol. 1. Academic Press Inc., New York, 1951 , P. 878. 